Brief Report

\title{
Effect of the Presence of Virus-like Particles on Bacterial Growth in Sunlit Surface and Dark Deep Ocean Environments in the Southern East China Sea
}

\author{
An-Yi Tsai ${ }^{1,2}$, Ying-Tsong Lin $^{3}$ and Gwo-Ching Gong 1,2,* \\ 1 Institute of Marine Environment and Ecology, National Taiwan Ocean University, Keelung 202-24, Taiwan; \\ anyitsai@mail.ntou.edu.tw \\ 2 Center of Excellence for the Oceans, National Taiwan Ocean University, Keelung 202-24, Taiwan \\ 3 Woods Hole Oceanographic Institution, Woods Hole, MA 02543, USA; ytlin@whoi.edu \\ * Correspondence: gcgong@mail.ntou.edu.tw; Tel.: +886-2-2462-2192 (ext. 5701); Fax: +886-2-2462-0892
}

Citation: Tsai, A.-Y.; Lin, Y.-T.; Gong, G.-C. Effect of the Presence of

Virus-like Particles on Bacterial Growth in Sunlit Surface and Dark Deep Ocean Environments in the Southern East China Sea. Water 2021, 13, 2934. https://doi.org/10.3390/ w13202934

Academic Editor: Sandi Orlić

Received: 3 September 2021

Accepted: 14 October 2021

Published: 19 October 2021

Publisher's Note: MDPI stays neutral with regard to jurisdictional claims in published maps and institutional affiliations.

Copyright: (c) 2021 by the authors. Licensee MDPI, Basel, Switzerland. This article is an open access article distributed under the terms and conditions of the Creative Commons Attribution (CC BY) license (https:// creativecommons.org/licenses/by/ $4.0 /)$.

\begin{abstract}
Virus-like particles (VLPs) are thought to increase the dissolved organic carbon by releasing the contents of the host cell, which, in turn, can affect bacterial growth in natural aquatic environments. Yet, experimental tests have shown that the effect of VLPs on the bacterial growth rate at different depths has seldom been studied. Bacteria-VLP interaction and the effect of VLPs on bacterial growth rate in the sunlit surface $(3 \mathrm{~m})$ and dark, deep ocean $(130 \mathrm{~m})$ environments were first explored at a test site in the southern East China Sea of the northwest Pacific. Our experimental results indicated that bacterial and virus-like particle (VLP) abundance decreased with depth from

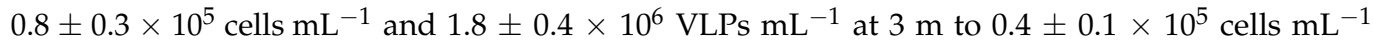
and $1.4 \pm 0.3 \times 10^{6} \mathrm{VLPs} \mathrm{mL}^{-1}$ at $130 \mathrm{~m}$. We found that the abundance of VLPs to Bacteria Ratio $(\mathrm{VBR})$ in the dark deep ocean $(\mathrm{VBR}=35.0 \pm 5.6)$ was higher than in the sunlit surface environment $(\mathrm{VBR}=22.5 \pm 2.1)$. The most interesting finding is that in the dark, deep ocean region the bacterial growth rate in the presence of VLPs was higher $\left(0.05 \mathrm{~h}^{-1}\right)$ than that in virus-diluted treatments $\left(0.01 \mathrm{~h}^{-1}\right)$. However, there was no significant difference in the bacterial growth rates between the treatments in the sunlit surface ocean region. Deep-sea ecosystems are dark and extreme environments that lack primary photosynthetic production, and our estimates imply that the contribution of recycled carbon by viral lysis is highly significant for bacterial growth in the dark, deep ocean environment. Further work for more study sites is needed to identify the relationship of VLPs and their hosts to enable us to understand the role of VLPs at different depths in the East China Sea.
\end{abstract}

Keywords: VLP production; East China Sea; VLPs to bacteria ratio; bacterial growth rates; VLP abundance

\section{Introduction}

Recent studies concerning large numbers of virus-like particles (VLPs) range from $10^{4}$ to $10^{8}$ VLPs $\mathrm{mL}^{-1}$ in both freshwater and marine environments, given that the potential viral lysis may be an important process in altering the carbon flow within the microbial loop [1-3]. In addition, VLPs play a major role in the aquatic microbial food web by recycling large amounts of carbon and nutrients within the viral loop [4-6], which, in turn, can affect the bacterial community growth and structure [7].

Knowledge of the abundance of VLPs is essential for the microbial ecology of the aquatic environments [3]. However, the factors influencing VLP abundance and dynamics are complex. An important first step for studying the ecological significance of VLPs in aquatic ecosystems must be to recognize their interaction with their hosts (e.g., bacteria). In most occurrences, VLP abundance has a significantly positive correlation with the changes in bacterial abundance or $\mathrm{Chl} a$ concentration [8-12]. Furthermore, the correlation of bacterial and VLP abundance suggests that bacterial cells are the principal VLP hosts and 
support VLP production in aquatic environments [9-11]. Our knowledge about variations of VLP-host interactions and their variability in a changing marine environment is still scarce. Furthermore, VLP abundance and activity appear to vary in relation to some factors, such as the environmental trophic state, oxygen concentration and water depth, temperature, and the UV light level [13-17]. Physiochemical changes with depth (e.g., the nutrients, temperature, and UV light level) can have a significant impact on planktonic micro-organisms, and these environmental and biological factors (bacterial growth) will then have an effect on the vertical changes in VLP abundance and production [18]. Previous observations have shown marked differences in the relationship between the VLPs and bacterial abundance in different marine environments. For example, the VLPs to Bacteria Ratio (VBR) is about 10 in the surface waters of the Arctic Ocean [19]. In contrast, in the deep waters of the Atlantic Ocean the VBR often exceeds 100 [20]. However, the ecological studies on the bacteria-VLP interaction at different depths in marine environments remain largely unquantified, and the reasons for these differences are unknown. To answer questions concerning the impact of VLPs on marine ecosystems and identify constraints on VLP activity, we must first examine VLP associated parameters (such as VLP production) in our study region.

Besides this, it is generally accepted that lysed bacteria cells stimulate bacterial production through the release of nutrients and carbon back into the dissolved fraction, and previous field experiments have provided evidence that the regeneration of nutrients by viral lysis may be important in some environments $[6,21,22]$. Lysate contains nutrient-rich molecules such as amino acids and dissolved-DNA (D-DNA; [23]) and is an important nutrient source in oligotrophic environments. For example, in Danish coastal waters under P-limited conditions, VLPs release D-DNA, which is taken up for about $50 \%$ of the bacterial $\mathrm{P}$ demand [24]. However, a few reports indicated that VLP-bacteria interactions in aquatic environments are related to the growth rates of the bacteria [25], and it is difficult to draw conclusions on the role of VLPs in bacterial growth in complex natural systems.

In this paper, we took preliminary samples from a single site and presented the measurements of bacterial and VLP abundance, bacterial growth rate, and VLP production in the sunlit surface $(3 \mathrm{~m})$ and dark, deep ocean environment $(130 \mathrm{~m})$ in the southern East China Sea, in October 2020. This is, to our knowledge, the first study examining the role of VLPs from surface to deep waters in the southern East China Sea. We hypothesized that the bacterial and VLP abundance, bacterial growth rate, and VLP production would differ between the sunlit surface and the dark, deep ocean layer, due to the physiochemical changes with depth.

\section{Materials and Methods}

\subsection{Study Site and Samplings}

Samples were collected between 25-27 October 2020, from depths of $3 \mathrm{~m}$ and $130 \mathrm{~m}$ at an established station located in the southern East China Sea $\left(122.027^{\circ} \mathrm{E}, 25.413^{\circ} \mathrm{N}\right)$ (Figure 1A) on board the R/V Ocean Research II. The euphotic depth is defined as a depth of $1 \%$ surface light penetration, and the euphotic depth of this study site is $57 \mathrm{~m}$. On this cruise, seawater samples were collected using a $12 \mathrm{~L}$ Teflon-coated Go-Flo bottle. The seawater temperature and salinity were measured by SBE 9/11plus CTD (Sea-Bird Scientific). Water samples were filtered ( $25 \mathrm{~mm} \mathrm{GF} / \mathrm{F}$ ) for Chl $a$ analysis and measured after extraction with an in vitro fluorometer (Turner Design 10-AU-005) [26]. Seawater samples for nutrient analysis were placed in 100-mL polypropylene bottles and immediately frozen in liquid nitrogen. The phosphate concentration was measured by molybdenum blue method [27]. The precision in the measurements of phosphate was $\pm 0.01 \mu \mathrm{M}$ [26]. 

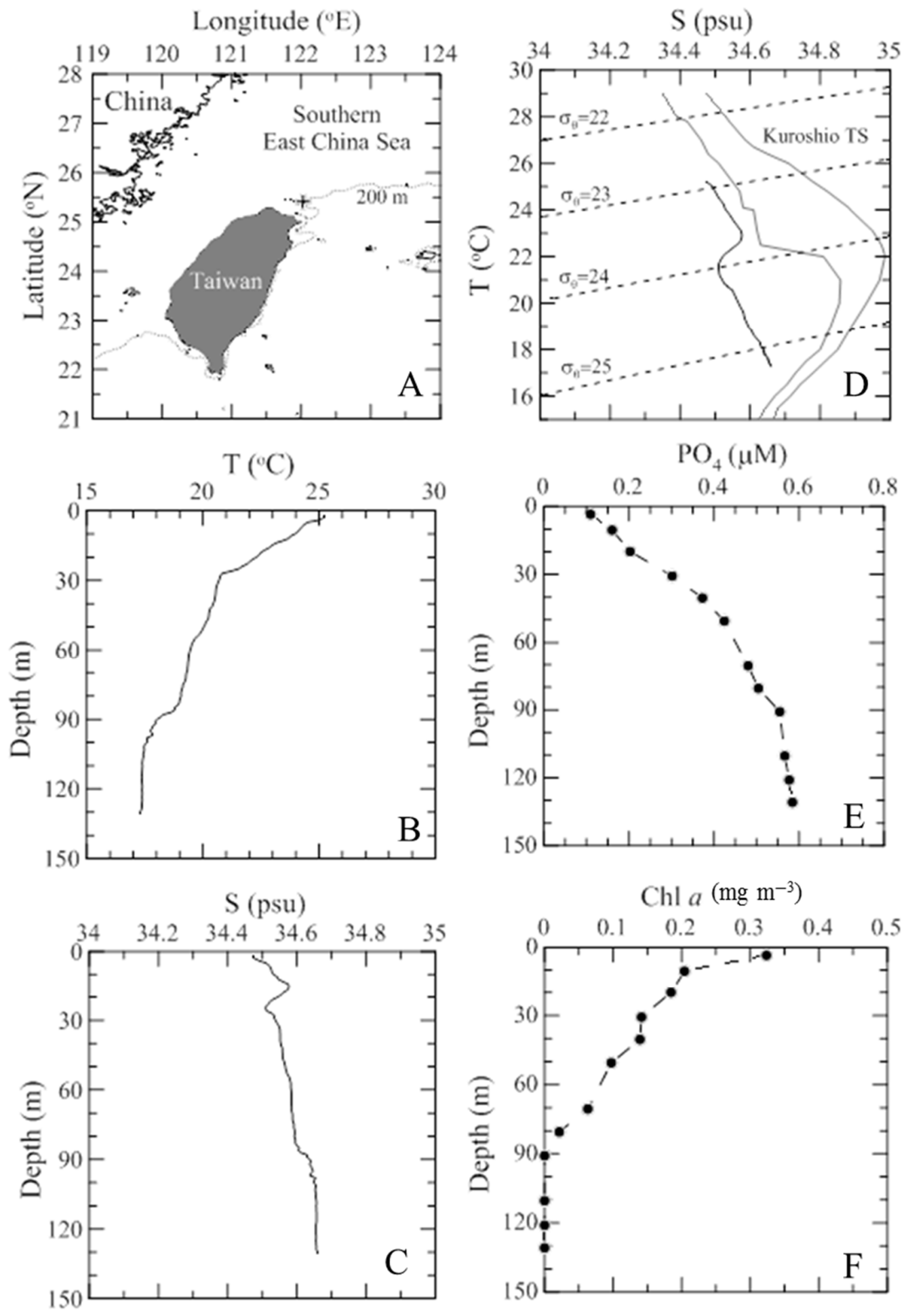

Figure 1. Map of the southern East China Sea showing the location of the sampling site (+) (A). Vertical variations of temperature (B) and salinity $(\mathbf{C})$ throughout the water column. Temperature-salinity (T-S) diagram of the processed CTD data and typical Kuroshio water (KW) is plotted for reference (D). Vertical variations of $\mathrm{PO}_{4}(\mathrm{E})$ and $\mathrm{Chl} a$ concentrations $(\bullet)$ (F) throughout the water columns during the study period.

\subsection{VLP Production}

In brief, the grazing-free whole water for the experiment was prepared by gently vacuum-filtering $2 \mathrm{~L}$ of surface and dark, deep seawater through a $47 \mathrm{~mm}$ diameter, $2 \mu \mathrm{m}$ pore-size polycarbonate track-etched filter membrane (Whatman). For VLP dilu- 
tion, $500 \mathrm{~mL}$ of VLP-free water was produced by filtering grazer-free seawater through a Minimate TFF Capsule (Pall), with a $30 \mathrm{kDa}$ molecular weight cut-off. The removal of VLPs through $30 \mathrm{kDa}$ TFF does not fundamentally change the carbon and nutrient composition and the bacterial assemblage in the water, thus, with slight manipulations, this method is suitable for VLP dilution studies [6]. Dilution was performed by adding $400 \mathrm{~mL}$ of the VLP-free water to $100 \mathrm{~mL}$ of grazer-free water, and decreasing the bacterial and VLP density to approximately $20 \%$ of the original seawater. The diluted incubation water was thoroughly mixed and filled in $50 \mathrm{~mL}$ plastic incubation tubes. Immediately after preparation, the bottles were moved outside onto the deck and then incubated for $12 \mathrm{~h}$ under natural light and neutral-density plastic sheets (Lee Filters, Hampshire, UK), which were used to simulate the light intensity at the sampling depth $(3 \mathrm{~m})$ in a thermo-controlled incubator; the bottom layer samples were incubated in the dark at the in situ temperature, and all treatments were performed in triplicate. To determine the bacterial and VLP abundance, sub-samples of $1 \mathrm{~mL}$ were taken at the beginning of the experiment, and every $1 \mathrm{~h}$, for a $12 \mathrm{~h}$ period. VLP production (VP) (VLPs $\mathrm{mL}^{-1} \mathrm{~h}^{-1}$ ) was calculated using the linear regression between the VLP density and incubation time. While a significant linear relationship was observed between the VLP density and incubation time, the VP was defined as the slope of regression [28].

\subsection{Effect of VLP Presence on Bacterial Growth}

In order to get a better understanding of how the presence of VLPs affects bacterial growth, the bacterial growth rate was measured in both the 20\% diluted (VLP-free water diluted with $<2 \mu \mathrm{m}$ filtered waters; VLPs diluted $)$ and grazing-free $(<2 \mu \mathrm{m}$ filtered waters; VLPs present) samples. Moreover, the changes in the bacterial growth rates were compared with the VLP-present and VLP-diluted samples, which can provide a complete view of the actual role of VLPs in our study region. The bacterial growth rate was calculated as follows:

$$
\mu=\ln \left(\mathrm{N}_{\mathrm{t}} / \mathrm{N}_{0}\right) / \mathrm{t}
$$

where $\mu$ is the growth rate $\left(\mathrm{h}^{-1}\right), \mathrm{N}_{0}$ and $\mathrm{N}_{\mathrm{t}}$ are the abundance of bacteria at the beginning and end of incubation, and $t$ is the incubation time $(12 \mathrm{~h})$. All treatments were performed in triplicate.

We detected a statistically significant difference between both treatments, and the values of bacterial growth rates in $20 \%$ diluted (VLPs diluted) was higher than that in the samples with VLPs $(<2 \mu \mathrm{m}$ filtered waters; VLPs present). Thus, we suggest that topdown control (viral lysis) is the main factor in controlling bacteria. However, in contrast, the bacterial growth rate in a $20 \%$ diluted treatment was lower than that in the samples with VLPs present, which implied that bottom-up control is the most important factor for limiting bacterial growth. This suggests that VLPs can have a significant effect on nutrient and carbon regeneration by enhancing the bacterial growth rate in our study region.

\subsection{Enumeration of VLPS and Host Density by Flow Cytometry (FCM)}

VLPs and bacterial samples were analyzed using a CytoFLEX S flow cytometer (Beckman Coulter, Indianapolis, IN, USA) equipped with a $488 \mathrm{~nm}$ air-cooled argon-ion laser, a standard $525 \mathrm{~nm}$ filter, and an SYBR signal trigger. Briefly, the samples for enumeration of VLPs were diluted 10-fold with 0.2- $\mu \mathrm{m}$ filtered TE buffer ( $\mathrm{pH}$ 8.0, EM grade) prior to staining, to minimize the interference from high particle density. The diluted samples were stained with SYBR Green I (final concentration 1:50,000 of commercial stock) and incubated in the dark at $80^{\circ} \mathrm{C}$ for $10 \mathrm{~min}$. After staining, samples were cooled in an ice bath to $25^{\circ} \mathrm{C}$ and processed through FCM according to the method of Brussaard [29]. Blank controls of TE buffer stained with the same concentration of SYBR Green I were run for detecting and eliminating any noise from the buffer. Bacterial samples were stained with SYBR Green I (final concentration 1:10,000) at room temperature for $15 \mathrm{~min}$ in the dark and processed through FCM according to the protocol of Hammes and Egli [30]. 


\subsection{Statistical Analysis}

The relationship between VLP abundance and the time of triplicate incubation was analyzed using a linear regression analysis. The significance of slope was tested using an Analysis of Variance (ANOVA). The growth rate of bacteria in VLP-present and VLPdiluted samples were compared and analyzed using the non-parametric Mann-Whitney test. STATISTICA 7.0 software was used for all statistical operations. A probability value of $<0.05$ was considered to be significant.

\section{Results and Discussion}

\subsection{Environmental Dynamics}

The vertical patterns that are characteristic of the physiochemical and biological parameters during the study period are shown in Figure 1. The temperature in the surface water reached $25.2^{\circ} \mathrm{C}$, while it was $17.3^{\circ} \mathrm{C}$ near the bottom (Figure 1B). The salinity ranged from $34.47 \mathrm{psu}(3 \mathrm{~m})$ to $34.66 \mathrm{psu}(130 \mathrm{~m})$ (Figure 1C). Figure 1D shows the T-S diagram for the vertical values of the CTD data, and the T-S curves of the typical Kuroshio Water (KW) is plotted for reference. The results showed that part of the Upwelled Kuroshio Subsurface Water (UKSW) might be intruded upon and that it formed a pool of cold, salty water near the bottom (Figure 1D). Furthermore, the current data of the temperature and salinity distribution in the upper $30 \mathrm{~m}$ was observed, indicating a high temperature-salinity of the Kuroshio Surface Waters (KSW) intrusion in the upper water column (Figure 1D). The influence of the UKSW has been shown to be present at the shelf-break northeast of Taiwan all year round [31]. The concentrations of $\mathrm{PO}_{4}$ ranged from 0.11 to $0.58 \mu \mathrm{M}$ and increased from the surface to the bottom waters (Figure 1E). Furthermore, the Chl $a$ concentrations decreased from the surface to the bottom water, and ranged from 0.375 to non-detectable (Figure 1F). In particular, we noted the vertical changes in the $\mathrm{PO}_{4}$ concentrations in our study. It was reported that viral production is often limited by phosphorus in aquatic environments [32], since it is a significant component of DNA, and DNA comprises a large portion of the virus particles [33]. However, based on the above analyses of environmental data, due to influence of the UKSW and the upwelling nutrient intrusion on the dark bottom waters, nutrients may not be a limiting factor for viral production in the dark, deep region in this study.

\subsection{Bacteria-VLP Interaction}

Our experimental results indicated that the bacterial and VLP abundance decreased with depth, from $0.8 \pm 0.3 \times 10^{5}$ cells $\mathrm{mL}^{-1}$ and $1.8 \pm 0.4 \times 10^{6} \mathrm{VLPs} \mathrm{mL}^{-1}$ at $3 \mathrm{~m}$ of depth to $0.4 \pm 0.1 \times 10^{5}$ cells $\mathrm{mL}^{-1}$ and $1.4 \pm 0.3 \times 10^{6} \mathrm{VLPs} \mathrm{mL}^{-1}$ in the dark, deep ocean region (Table 1). Furthermore, bacterial and VLP abundance decreased by almost $50 \%$ and $22 \%$, respectively, from the sunlit surface to the dark, deep ocean environment during the study period. Previous studies have observed that the VLP abundance in the epipelagic regions is significantly higher than in the mesopelagic regions $[2,18,34]$. Furthermore, the vertical distribution of VLP abundance is influenced by the plankton processes, and the VLPs varied concordantly with the bacterial abundance, Chl $a$, and the picophytoplankton abundance, which decreased with depth [35,36]. The results of our present study support such an observation of the relatively high Chl $a$ concentration and bacterial abundance in the sunlit surface ocean waters (Table 1). Besides these biological factors, the temperature may also be an important factor in controlling the vertical changes in VLP abundance, because the temperature has a significant effect on bacterial growth and production [37]. During this study, the in situ temperature varied by $8{ }^{\circ} \mathrm{C}$ from surface to deep waters (Figure 1B). It is also interesting to note that our results clearly observed that the VLP abundance decreased less than the bacteria with depth, which is similar to previous observations [18,38], and resulted in higher VLPs to Bacteria Ratio (VBR) (35 \pm 5.6$)$ in the dark, deep ocean, compared to the sunlit surface ocean layer (22.5 \pm 2.1$)$ (Table 1). Although there are no previous studies on VLP abundance in the southern East China Sea, in other studies in different marine environments, the VBR is about 10 (e.g., in the surface 
waters of the Arctic Ocean) [19]. In contrast, in the deep waters of the Atlantic Ocean the VBR often exceeds 100 [20]. The present study confirms the previous observations and extends our knowledge on the distribution of VLP abundance from the sunlit surface to the dark, deep ocean environment.

The VBR is often used as an indicator for the relationship between bacteria and VLPs. Taken together with other studies of the marine and freshwater environment, the VBR has been reported to vary from 0.03 to 80, suggesting that VLPs are a highly dynamic component of the aquatic food web [34]. Previous studies have suggested that VBR values $>10$ indicate that VLP infection might be responsible for a large fraction of bacterial mortality $[34,39]$. Thus, a high VBR in dark, deep ocean regions implied important bacteria-VLP interactions in this study. Other studies also indicate that the impact of VLPs on bacteria is more significant in deeper waters than at the surface $[18,36,40]$. The values of the VBR are the result of a comprehensive balance of factors, such as VLP production, the transport of viruses through sinking particles, and the decay rates [28,41]. In our case, the VLP production (VP) is not applicable for explaining the high VBR value in a dark, deep ocean environment because the VP is low in the region of this study (Figure 2; Table 1).

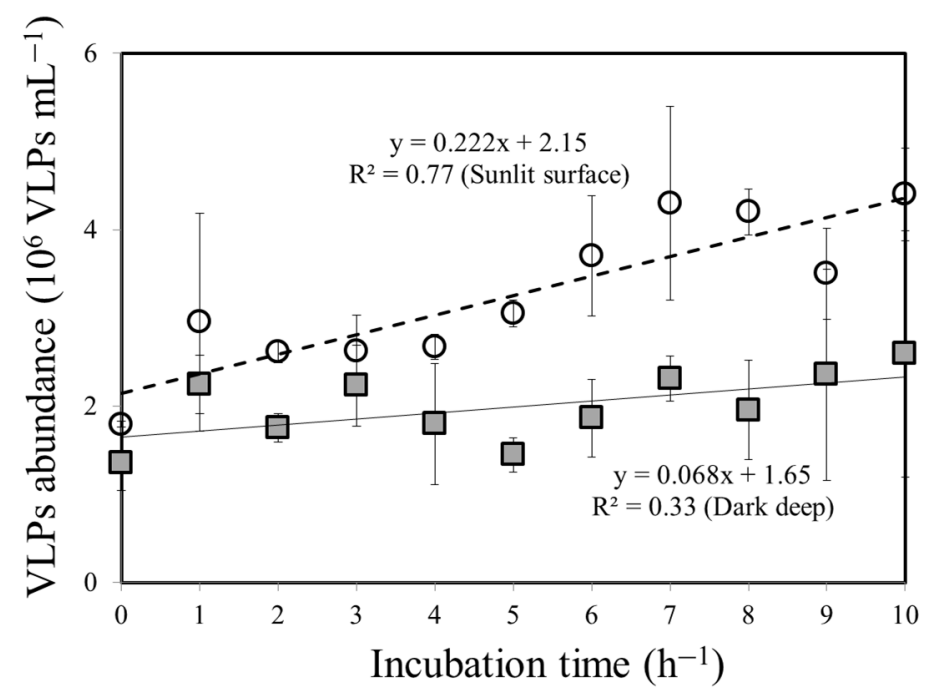

Figure 2. Relationship between VLP abundance and incubation time in the sunlit surface (O) and dark, deep ocean environment $(\boldsymbol{\square})$. (-) and (-) are the regression lines for sunlit surface and dark deep water, respectively.

The changes in VLP abundance that were observed in the sunlit surface and dark, deep ocean environment during the experiment for measuring VP are illustrated in Figure 2. The values of VP were about 3.3 times higher in the sunlit surfaces $\left(0.222 \times 10^{6} \mathrm{VLPs} \mathrm{mL}^{-1} \mathrm{~h}^{-1}\right)$ than in the dark, deep ocean region $\left(0.068 \times 10^{6} \mathrm{VLPs} \mathrm{mL}^{-1} \mathrm{~h}^{-1}\right)$ (Figure 3, Table 1). In this study with a high VP characterized by a relatively low value of VBR in sunlit surface waters, VLP abundance could be partially underestimated, due to the environmental factors in this region. One possible explanation is that the impact of high levels of solar radiation (particularly UV) can damage VLP DNA in the sunlit surface waters, thereby reducing VLP activity and abundance [2]. These findings have led us to hypothesize that this abiotic factor, namely the damage of UV on viruses, could play an important role in removing viruses in sunlit surface waters. Another explanation is that nanoflagellate communities are abundant in surface waters, and may actively graze on VLPs for their food, with the potential removal of VLPs being $1.25 \%$ per day of the total VLPs in summer [42]. Although we did not directly measure the impact of nanoflagellate grazing on VLPs and the VLP decay rate in our samples, we cannot exclude these possible factors in this region. 


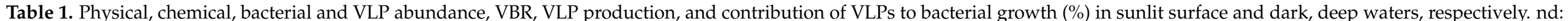
non detectable. a: Ratio of $<2 \mu \mathrm{m}$ filtered water to ((value of $<2 \mu \mathrm{m}$ filtered water)-(value of $20 \%$ diluted water)).

\begin{tabular}{|c|c|c|c|c|c|c|c|c|c|c|}
\hline & Temperature & $\mathrm{PO}_{4}$ & Chl $a$ & $\begin{array}{c}\text { Bacterial } \\
\text { Abundance }\end{array}$ & VLPs Abundance & VBR & $\begin{array}{c}\text { VLPs } \\
\text { Production }\end{array}$ & $\begin{array}{c}\text { Net Growth } \\
\text { Rate in } 20 \% \\
\text { Diluted Water }\end{array}$ & $\begin{array}{l}\text { Net Growth } \\
\text { Rate in }<2 \mu \mathrm{m} \\
\text { Filtered Water }\end{array}$ & $\begin{array}{l}\text { Contribution of } \\
\text { VLPs to Bacterial } \\
\text { Growth (\%) }\end{array}$ \\
\hline & $\left({ }^{\circ} \mathrm{C}\right)$ & $(\mu \mathrm{M})$ & $\left(\mathrm{mg} \mathrm{m}^{-3}\right)$ & $\left(10^{5}\right.$ cells $\left.\mathrm{mL}^{-1}\right)$ & $\begin{array}{c}\left(10^{6} \text { viruses }\right. \\
\left.\mathrm{mL}^{-1}\right)\end{array}$ & & $\begin{array}{l}\left(10^{6} \text { viruses }\right. \\
\left.\mathrm{mL}^{-1} \mathrm{~h}^{-1}\right)\end{array}$ & $\left(h^{-1}\right)$ & $\left(h^{-1}\right)$ & $(\%)$ \\
\hline Surface water & 25.2 & 0.11 & 0.375 & $0.8 \pm 0.3$ & $1.8 \pm 0.4$ & $22.5 \pm 2.1$ & 0.222 & $0.10 \pm 0.02$ & $0.12 \pm 0.05$ & $17 \%$ \\
\hline Deep water & 17.3 & 0.58 & nd & $0.4 \pm 0.1$ & $1.4 \pm 0.3$ & $35 \pm 5.6$ & 0.068 & $0.01 \pm 0.005$ & $0.05 \pm 0.02$ & $80 \%$ \\
\hline
\end{tabular}




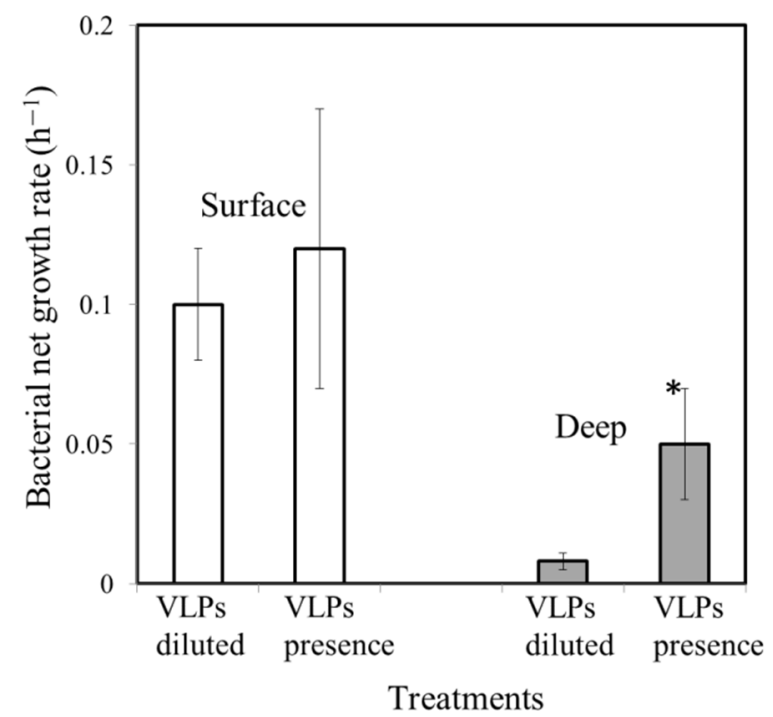

Figure 3. Bacterial net growth rates in $20 \%$ diluted (VLPs diluted) and grazing-free ( $<2 \mu \mathrm{m}$ filtered waters; VLPs present) treatments in the sunlit surface $(\square)$ and dark, deep waters $(\square)$, respectively. *: difference is significant at the 0.05 level.

VLP decay rates often increase with light and temperature [43]. Thus, the low temperature and irradiance level of the dark, deep ocean environment could result in a lower decay rate than in the warmer surface waters [20]. This decrease in the VLP decay rate with depth might contribute to the higher VBR in the dark, deep waters in our experiments (Table 1). An accurate analysis of viral dynamics requires independent estimations of VLP abundance, production, and decay rates. Furthermore, Hara et al. [44] discussed the possibility of the allochthonous input of VLPs from surface waters into the deep layers of the Pacific, which may explain the high bathypelagic VLP abundance. We showed that the VP in the dark, deep ocean is about 3.3 times lower than in the sunlit surface waters. Thus, we suggest that VLPs attached to particles derived from the surface waters are an important source for deep-water VLPs.

\subsection{Effect of VLP Presence on Bacterial Growth Rate}

The surface waters of the study region were characterized by high bacterial growth rates of about 0.1 and $0.12 \mathrm{~h}^{-1}$ in the VLP-diluted and VLP-present treatments (Figure 3, Table 1), respectively, and there was no significant difference in the bacterial growth rates between them ( $p>0.05$, Mann-Whitney test). In this study, VLP-induced bacterial mortality was not important for controlling the bacterial abundance in sunlit surface waters. On the other hand, grazing by nanoflagellates should be considered as an important causative agent of bacterial mortality in this region. The observations of previous studies in the coastal waters of the subtropical western Pacific have suggested that nanoflagellate grazing was responsible for most of the bacterial mortality $(81-87 \%)$, relative to viral lysis in the surface waters ( $3 \mathrm{~m}$ depth), while viral lysis was responsible for $67-75 \%$ of the total bacterial mortality in the deep waters (135 $\mathrm{m}$ depth) [45]. This vertical pattern is similar to previous results obtained in other regions, which found that grazing generally dominates in surface waters, whereas viral lysis is more prominent in deeper waters [40,46]. Conversely, in a study in a large mesotrophic lake (Lake Biwa, Japan), in the deeper layer, grazing-induced bacterial mortality was greater than viral lysis [47].

One of the most interesting findings in this study is that the bacterial growth rate with the VLPs present was higher $\left(0.05 \mathrm{~h}^{-1}\right)$ than that in VLP-diluted treatments $\left(0.01 \mathrm{~h}^{-1}\right)$ $(p<0.05$, Mann-Whitney test) (Figure 3, Table 1) in the dark, deep ocean region. In this case, the bacterial growth rate was clearly lower in treatments in which the VLP abundance was reduced (Figure 3, Table 1), which suggests that the presence of active VLPs will stimulate 
bacterial growth. It is worth noting that the high carbon, nitrogen, and phosphorus content of bacteria is released into the environment after lysis, and it is not surprising that it stimulates the growth of non-infected bacteria [48]. Deep-sea ecosystems are dark and extreme environments that lack photosynthetic primary production. Our estimates imply that there is a highly significant fraction of recycled carbon and nutrients by viral lysis that contribute to the bacterial growth $(80 \%)$ in the dark, deep layer in this study (Table 1 ). Thus, the viral loop (the flow of carbon among bacteria, VLPs, and the DOC pool) can comprise much of the carbon flow in the dark, deep waters in this study.

This paper concludes that physiochemical changes (e.g., nutrients and temperature) with depth can have a significant impact on the bacterial and Chl $a$ concentrations, and that these environmental and biological factors (bacterial growth) will then have an effect on the vertical changes in VP. In this study, a high VP is characterized by a relatively low value of VBR in sunlit surface waters, and VLP abundance could therefore be partially underestimated because of the environmental factors in this region. In future studies, we will focus on assessing the effects of solar influence on VLP populations, as well as their decay rates with the VLP seasonal oscillations, and we will investigate more fully the solar influence on the microbial dynamics at different depths on the subtropical aquatic systems. Furthermore, we would suggest that VLPs play a much more prominent role in carbon cycling, with the possible implication of enhanced bacterial productivity and growth in the dark, deep ocean environment.

Author Contributions: Conceptualization: A.-Y.T.; methodology: A.-Y.T.; validation: A.-Y.T.; formal analysis: A.-Y.T.; investigation: A.-Y.T. and Y.-T.L.; resources: A.-Y.T.; data curation: A.-Y.T.; writing-original draft preparation: A.-Y.T. and G.-C.G.; writing—review and editing: A.-Y.T. and G.-C.G.; funding acquisition: A.-Y.T. and G.-C.G. All authors have read and agreed to the published version of the manuscript.

Funding: The research was supported by RFBR projects 18-44-920026, and the Ministry of Science and Technology, Taiwan, grant number NSC 109-2611-M-019-013 and NSC 110-2611-M-019-005.

Institutional Review Board Statement: Not applicable.

Informed Consent Statement: Not applicable.

Acknowledgments: We appreciate the language editing and helpful comments related to this manuscript from Choice Language Service.

Conflicts of Interest: The authors declare no conflict of interest.

\section{References}

1. Fischer, U.R.; Velimirov, B. High control of bacterial production by viruses in a eutrophic oxbowlake. Aquat. Microb. Ecol. 2002, 27, 1-12. [CrossRef]

2. Weinbauer, M.G. Ecology of prokaryotic viruses. FEMS Microbiol. Rev. 2004, 28, 127-181. [CrossRef]

3. Suttle, C.A. Marine viruses-Major players in the global ecosystem. Nat. Rev. Microbiol. 2007, 5, 801-812. [CrossRef]

4. Weinbauer, M.G.; Rassoulzadegan, F. Are viruses driving microbial diversification and diversity? Environ. Microbiol. 2004, 6, 1-11. [CrossRef] [PubMed]

5. Haaber, J.; Middelboe, M. Viral lysis of Phaeocystis pouchetii: Implications for algal population dynamics and heterotrophic C, N and P cycling. ISME J. 2009, 3, 430-441. [CrossRef] [PubMed]

6. Shelford, E.J.; Middelboe, M.; Moller, E.F.; Suttle, C.A. Virus-driven nitrogen cycling enhances phytoplankton growth. Aquat. Microb. Ecol. 2012, 66, 41-46. [CrossRef]

7. Riemann, L.; Middelboe, M. Stability of bacterialand viral community compositions in Danish coastal watersas depicted by DNA fingerprinting techniques. Aquat. Microb. Ecol. 2002, 27, 219-232. [CrossRef]

8. Cochlan, W.P.; Wikner, J.; Steward, G.F.; Smith, D.C.; Azam, F. Spatial distribution of viruses, bacteria and chlorophyll a in nertic, oceanic and estuarine environments. Mar. Ecol. Prog. Ser. 1993, 92, 77-87. [CrossRef]

9. Bettarel, Y.; Sime-Ngando, T.; Amblard, C.; Carrias, J.F.; Portelli, C. Virioplankton and microbial communities in aquatic systems: A seasonal study in two lakes of differing trophy. Freshw. Biol. 2003, 48, 810-822. [CrossRef]

10. Peduzzi, P.; Schiemer, F. Bacteria and viruses in the water column of tropical freshwater reservoirs. Environ. Microbiol. 2004, 6, 707-715. [CrossRef]

11. Fernandes, A.; Arau'jo, F.; Godinho, M.J.L. Short-term variations of virus-like particles in a tropical lake: Relationship with microbial communities (bacteria, ciliates and flagellates). Microbiol Res. 2009, 164, 411-419. 
12. Tsai, A.Y.; Gong, G.C.; Liu, H. Seasonal variations in virioplankton and picoplankton in semi-enclosed and open coastal waters. Terr. Atmos. Ocean. Sci. 2018, 29, 465-472. [CrossRef]

13. Mathias, C.B.; Kirschner, K.T.; Velimirov, B. Seasonal variations of virus abundance and viral control of the bacterial population in backwater system of the Danube River. Appl. Environ. Microbiol. 1995, 61, 3734-3740. [CrossRef] [PubMed]

14. Weinbauer, M.G.; Fuks, D.; Puskaric, S.; Peduzzi, P. Diel, seasonal and depth-related variability of viruses and dissolved DNA in the northern Adriatic Sea. Microb. Ecol. 1995, 30, 25-41. [CrossRef] [PubMed]

15. Weinbauer, M.G.; Höfle, M.G. Significance of viral lysis and flagellate grazing as factors controlling bacterioplankton production in a eutrophic lake. Appl. Environ. Microbiol. 1998, 64, 431-438. [CrossRef] [PubMed]

16. Wommack, K.E.; Hill, R.T.; Muller, T.A.; Colwell, R.R. Effects of sunlight on bacteriophage viability and structure. Appl. Environ. Microbiol. 1996, 62, 1336-1341. [CrossRef] [PubMed]

17. Sime-Ngando, T.; Bettarel, Y.; Chartogne, C.; Sean, K. The imprint of wild viruses on freshwater microbial ecology. Recent Res. Dev. Microbiol. 2003, 7, 481-497.

18. Magiopoulos, I.; Pitta, P. Viruses in a deep oligotrophic sea: Seasonal distribution of marine viruses in the epi-, meso- and bathypelagic waters of the Eastern Mediterranean Sea. Deep. Sea Res. Part I 2012, 66, 1-10. [CrossRef]

19. Clasen, J.L.; Brigden, S.M.; Payet, J.P.; Suttle, C.A. Evidence that viral abundance across oceans and lakes is driven by different biological factors. Freshw. Biol. 2008, 53, 1090-1100. [CrossRef]

20. Parada, V.; Sintes, E.; van Aken, H.M.; Weinbauer, M.G.; Herndl, G.J. Viral abundance, decay and diversity in the meso- and bathypelagic waters of the North Atlantic. Appl. Environ. Microbiol. 2007, 73, 4429-4438. [CrossRef]

21. Shelford, E.J.; Suttle, C.A. Virus-mediated transfer of nitrogen from heterotrophic bacteria to phytoplankton. Biogeosciences 2018, 15, 809-819. [CrossRef]

22. Gong, G.C.; Tsai, A.Y. Reduced daytime net growth rate of Synechococcus spp. in the East China Sea in summer estimated using a dilution approach. Estuar. Coast. Shelf Sci. 2019, 219, 90-96. [CrossRef]

23. Brum, J.R. Concentration, production and turnover of viruses and dissolved DNA pools at Stn ALOHA, North Pacific subtropical gyre. Aquat. Microb. Ecol. 2005, 41, 103-113. [CrossRef]

24. Granéli, E.; Wallström, K.; Larsson, U.; Granéli, W.; Elmgren, R. Nutrient limitation of primary production in the Baltic Sea area. AMBIO 1990, 19, 142-151.

25. Middelboe, M. Bacterial growth rate and marine virus-host dynamics. Microb. Ecol. 2000, 40, 114-124. [CrossRef] [PubMed]

26. Gong, G.C.; Shiah, F.K.; Liu, K.K.; Wen, Y.H.; Liang, M.H. Spatial and temporal variation of chlorophyll a, primary productivity and chemical hydrography in the southern East China Sea. Cont. Shelf. Res. 2000, 20, 411-436. [CrossRef]

27. Pai, S.C.; Yang, C.C.; Riley, J.P. Effects of acidity and molybdate concentration on the kinetics of the formation of the phosphoantimonyl molybdenum blue complex. Anal. Chim. Acta 1990, 229, 115-120.

28. Mei, M.L.; Danovaro, R. Virus production and life strategies in aquatic sediments. Limnol. Oceanogr. 2004, 49, 459-470. [CrossRef]

29. Brussaard, C.P.D. Optimization of procedures for counting viruses by flow cytometry. Appl. Environ. Microbiol. 2004, 70, 1506-1513. [CrossRef]

30. Hammes, F.; Egli, T. Cytometric methods for measuring bacteria in water: Advantages, pitfalls and applications. Anal. Bioanal. Chem. 2010, 397, 1083-1095. [CrossRef]

31. Gong, G.C.; Liu, K.K.; Pai, S.-C. Prediction of nitrate concentration from two end member mixing in the southern East China Sea. Cont. Shelf. Res. 1995, 5, 827-842. [CrossRef]

32. Williamson, S.J.; Paul, J.H. Nutrient stimulation of lytic phage production in bacterial populations of the Gulf of Mexico. Aquat. Microb. Ecol. 2004, 36, 9-17. [CrossRef]

33. Wilson, W.; Joint, I.; Carr, N.G.; Mann, N.H. The effect of phosphorus status on the kinetics of cyanophage infection in the oceanic cyanobacterium Synechococcus sp. WH7803. J. Phycol. 1996, 32, 506-516. [CrossRef]

34. Wommack, K.E.; Colwell, R.R. Virioplankton: Viruses in aquatic ecosystems. Microbiol. Mol. Biol. Rev. 2000, 64, 69-114. [CrossRef]

35. Boehme, J.; Frischer, M.E.; Jiang, S.C.; Kellogg, C.A.; Pichard, S.; Rose, J.B.; Steinway, C.; Paul, J.H. Viruses, bacterioplankton, and phytoplankton in the southeastern Gulf of Mexico: Distribution and contribution to oceanic DNA pools. Mar. Ecol. Prog. Ser. 1993, 97, 1-10. [CrossRef]

36. Taylor, G.T.; Hein, C.; Iabichella, M. Temporal variations in viral distributions in the anoxic Cariaco Basin. Aquat. Microb. Ecol. 2003, 30, 103-116. [CrossRef]

37. Maranger, R.; Bird, D.F. Viral abundances in aquatic systems: A comparison between marine and fresh waters. Mar. Ecol. Prog. Ser. 1995, 121, 217-226. [CrossRef]

38. Weinbauer, M.G.; Brettar, I.; Höfle, M.G. Lysogeny and virus-induced mortality of bacterioplankton in surface, deep, and anoxic marine waters. Limnol. Oceanogr. 2003, 48, 1457-1465. [CrossRef]

39. Yager, P.L.; Connelly, T.L.; Mortazavi, B.; Wommack, K.E.; Bano, N.; Bauer, J.E.; Opsahl, S.; Hollibaugh, J.T. Dynamic bacterial and viral response to an algal bloom at subzero temperatures. Limnol. Oceanogr. 2001, 46, 790-801. [CrossRef]

40. Colombet, J.; Sime-Ngando, T.; Cauchie, H.M.; Fonty, G.; Hoffmann, L.; Demeure, G. Depth-related gradients of viral activity in Lake Pavin. Appl. Environ. Microbiol. 2006, 72, 4440-4445. [CrossRef]

41. Wigington, C.H.; Sonderegger, D.; Brussaard, C.P.; Buchan, A.; Finke, J.F.; Fuhrman, J.A.; Lennon, J.T.; Middelboe, M.; Suttle, C.A.; Stock, C.; et al. Re-examination of the relationship between marine virus and microbial cell abundances. Nat. Microbiol. 2016, 1, 15024. [CrossRef] [PubMed] 
42. Laybourn-Parry, J.; Marshall, W.A.; Marchant, H.J. Nutritional versatility as a key to survival in Antarctic phytoflagellates in two contrasting saline lakes. Freshw. Biol. 2005, 50, 830-838. [CrossRef]

43. Bongiorni, L.; Magagnini, M.; Armeni, M.; Noble, R.; Danovaro, R. Viral production, decay rates, and life strategies along a trophic gradient in the north Adriatic sea. Appl. Environ. Microbiol. 2005, 71, 6644-6650. [CrossRef]

44. Hara, S.; Koike, I.; Terauchi, K.; Kamiya, H.; Tanoue, E. Abundance of viruses in deep oceanic waters. Mar. Ecol. Prog. Ser. 1996, 145, 269-277. [CrossRef]

45. Tsai, A.Y.; Gong, G.C.; Chao, C.F. Contribution of viral lysis and nanoflagellate grazing to bacterial mortality at surface waters and deeper depths in the coastal ecosystem of subtropical western Pacific. Estuaries Coasts 2016, 39, 1357-1366. [CrossRef]

46. Bettarel, Y.; Sime-Ngando, T.; Amblard, C.; Dolan, J. Viral activity in two contrasting lake ecosystems. Appl. Environ. Microbiol. 2004, 70, 2941-2951. [CrossRef]

47. Pradeep Ram, A.S.; Nishimura, Y.; Tomaru, Y.; Nagasaki, K.; Nagata, T. Seasonal variation in viral-induced mortality of bacterioplankton in the water column of a large mesotrophic lake (Lake Biwa, Japan). Aquat. Microb. Ecol. 2010, 58, $249-259$. [CrossRef]

48. Middelboe, M.; Jorgensen, N.O.G. Viral lysis of bacteria: An important source of dissolved amino acids and cell wall compounds. J. Mar. Biol. Assoc. UK 2006, 86, 605-612. [CrossRef] 